\title{
A Possible Industrial Solution to Ferment Lignocellulosic Hydrolyzate to Ethanol: Continuous Cultivation with Flocculating Yeast
}

\author{
Ronny Purwadi $^{1,3}$, Tomas Brandberg ${ }^{2}$ and Mohammad J. Taherzadeh ${ }^{3, *}$ \\ 1 Dept. of Chemical Engineering, Institut Teknologi Bandung, 40132 Bandung, Indonesia \\ 2 SEKAB, SE-891-26 Örnsköldsvik, Sweden \\ 3 School of Engineering, University College of Borås, S-501 90 Borås, Sweden; \\ Tel.: (+46) 33435 5908, Fax: (+46) 334354008
}

* Author to whom correspondence should be addressed; E-mail: Mohammad.Taherzadeh@hb.se

Received: 2 July 2007; in revised form: 9 August 2007 / Accepted: 28 August 2007 /

Published: 3 September 2007

\begin{abstract}
The cultivation of toxic lignocellulosic hydrolyzates has become a challenging research topic in recent decades. Although several cultivation methods have been proposed, numerous questions have arisen regarding their industrial applications. The current work deals with a solution to this problem which has a good potential application on an industrial scale. A toxic dilute-acid hydrolyzate was continuously cultivated using a highcell-density flocculating yeast in a single and serial bioreactor which was equipped with a settler to recycle the cells back to the bioreactors. No prior detoxification was necessary to cultivate the hydrolyzates, as the flocks were able to detoxify it in situ. The experiments were successfully carried out at dilution rates up to $0.52 \mathrm{~h}^{-1}$. The cell concentration inside the bioreactors was between 23 and $35 \mathrm{~g}-\mathrm{DW} / \mathrm{L}$, while the concentration in the effluent of the settlers was $0.32 \pm 0.05 \mathrm{~g}$-DW/L. An ethanol yield of $0.42-0.46 \mathrm{~g} / \mathrm{g}$-consumed sugar was achieved, and the residual sugar concentration was less than $6 \%$ of the initial fermentable sugar (glucose, galactose and mannose) of $35.2 \mathrm{~g} / \mathrm{L}$.
\end{abstract}

Keywords: Dilute-acid lignocellulosic hydrolysate, Saccharomyces cerevisiae, flocculating yeast, ethanol, glycerol, HMF, furfural, continuous cultivation 


\section{Introduction}

Ethanol is nowadays one of the most important renewable fuels on the market [1]. Its market has been triggered especially by the depletion of fossil fuel sources, as well as by its increasing demand. Ethanol may also be a resource for production of "green" plastic materials such as polyethylene, if its price can compete with oil on the market $[2,3]$. Ethanol is now predominantly produced from sugar sources such as sugar cane juice and starch sources such as corn and wheat grains [4-9]. Since these materials are also food for humans and/or animals, the limitations of stock and price may hinder these materials from being widely used in the future as feedstock for ethanol production. On the other hand, largely abundant lignocellulosic materials such as wastes of e.g. agricultural, forestry and paper-mill industries or dedicated energy crops (e.g. switchgrass) may be a sufficient and cheap feedstock for ethanol production [10,11]. Even though the commercial production of ethanol from lignocellulosic materials is still in development, it has been predicted that these materials will supply more than 50\% of ethanol in the future [1]. In such huge volume, fast and efficient overall processes are desirable to reduce investment and operating cost, thus making ethanol competitive with gasoline.

Fermentable sugars are obtained from lignocellulosic material through enzymatic or chemical hydrolysis processes [12-14]. There are great interests in the application of enzymatic hydrolysis due to its specific products and high yield [15]. Nevertheless, the time-consuming process and rather expensive enzyme cost make enzymatic hydrolysis still uncertain for use in large-scale industry. On the other hand, chemical hydrolysis processes leave more solid enhanced-lignin residuals, which could be burned in order to produce electricity and e.g. central heat or chill.

Formation of by-products in dilute-acid hydrolysis is another disadvantage of this process [13]. These are furan compounds produced from further hydrolysis of sugars, phenolic compounds as lignin decomposition products, and aliphatic acids which are products of hydrolysis or released from acetyl compounds [16-18]. These compounds inhibit cultivation of yeast in lignocellulosic hydrolyzates, hence a great effort has been made to avoid or solve this inhibition problem [19-22]. In general, since the fermenting microorganisms are able to detoxify the hydrolyzates in situ, any process that can provide low concentration of the inhibitors and high cell density may be successful in cultivation of these toxic hydrolyzates [19,20,23]. To some extent, continuous cultivation can provide low concentration of the inhibitors in the reactors [24] while the high cell density can be provided by using cell recycling [25], immobilization [26,27] or encapsulation [28,29].

Using cell recycling by e.g. centrifuges has been a popular method in industries for ethanol production from e.g. wheat. However, the toxicity of the lignocellulosic hydrolyzates and the presence of small particles in the hydrolyzate have not allowed this method to become well-developed yet [30]. Furthermore, high shear stress caused by centrifugation can significantly damage the cells, thus decreasing their viability [31].

Flocculating of yeast cells has been widely investigated and used for separating yeast cells from beer in the brewery industry [32]. A lectin-like protein forms so-called flocculins that stick out of the cell walls and selectively bind mannose residues present in adjacent yeast cells. This flocculating process is reversible, asexual and calcium-dependent. Since the cells can easily be separated in a simple settler, less mechanical stress and high cell viability can be maintained. 
In this study, the performance of flocculating yeast strain was studied in both batch and continuous cultivation. The laboratory strain of S. cerevisiae CBS 8066 was used as a reference for comparison since it used in many similar works [29,33-35]. In continuous cultivation, the flocculating yeast was separated from the effluent of the bioreactor using settler and recycled back into the bioreactor. In addition, a serial chemostat system was established in order to study the capability of the yeast to carry out in-situ detoxification in cultivation at high dilution rates.

\section{Material and Methods}

\subsection{Dilute-acid hydrolyzates}

Hydrolyzates used in this work were mixtures of $1^{\text {st }}$-stage (ca 20\%) and $2^{\text {nd }}$-stage (ca $80 \%$ ) hydrolyzates produced from a two-stage dilute-acid hydrolysis of spruce forest residual [36]. The composition of hydrolyzates was, in $\mathrm{g} / \mathrm{L}$ : galactose $(1.6 \pm 0.4)$, glucose $(27.5 \pm 3.5)$, mannose $(6.1 \pm 1.7)$, acetic acid (1.6 \pm 0.1$)$, furfural $(0.4 \pm 0.2)$, and hydroxymethyl furfural (HMF) (1.9 \pm 0.2$)$. The hydrolyzates were stored below $4{ }^{\circ} \mathrm{C}$ at low $\mathrm{pH}($ about $\mathrm{pH}=2)$ before use.

\subsection{Yeast strain and medium}

Flocculating yeast strain of $S$. cerevisiae, isolated from an ethanol plant (Domsjö Fabriker AB, Örnsköldsviks - Sweden) and registered at the Culture Collection in University of Göteborg (Sweden) as CCUG 53310, was used in all experiments. The lab strain Saccharomyces cerevisiae CBS 8066 obtained from Centraalbureau voor Schimmelcultures (Delft, the Netherlands) was also used for a comparative study. The strains were maintained on YPD agar plates $(10 \mathrm{~g} / \mathrm{L}$ of yeast extract, $20 \mathrm{~g} / \mathrm{L}$ of soy peptone, and $20 \mathrm{~g} / \mathrm{L}$ of $\mathrm{D}$-glucose as an additional carbon source). Inoculum cultures were aerobically grown in 250-mL cotton-plugged conical flasks in a shaker bath (rate of $115 \mathrm{rpm}$ and $1 \mathrm{~cm}$ eccentricity) at $30{ }^{\circ} \mathrm{C}$ for $24 \mathrm{~h}$. The liquid volume was $100 \mathrm{~mL}$ and the growth medium was a defined synthetic medium (DSM) as previously reported [37].

\subsection{Batch cultivation}

Batch cultivation was carried out in a 2.5-liter bioreactor (Biostat-A, B.Braun Biotech, Germany) with liquid volume of $2 \mathrm{~L}$ at $30^{\circ} \mathrm{C}, \mathrm{pH} 5.0$ and stirring rate of $500 \mathrm{rpm}$. Air was continuously purged at a rate of $800 \mathrm{~mL} / \mathrm{min}$ to perform aerobic cultivation, whereas $266 \mathrm{~mL} / \mathrm{min} \mathrm{N}_{2}$ was purged for anaerobic cultivation. The cultivation was started by an addition of $5 \mathrm{~mL}$ homogenized inoculum. The specific growth rate of the flocculating yeast was measured in aerobic conditions using $50 \mathrm{~g} / \mathrm{L}$ glucose as carbon and energy source in DSM. Anaerobic cultivations of this yeast were carried out by using different cultivation media: DSM with glucose as a sole carbon source, defined synthetic medium with hydrolyzate as a carbon source, and YPD (Yeast extract, Peptone, Dextrose) medium. All cultivation media were adjusted to contain initial total fermentable sugar (including glucose, galactose and mannose) of 27-29 g/L. In addition, an anaerobic cultivation was carried out by using S. cerevisiae CBS 8066 on defined synthetic medium for comparison. 


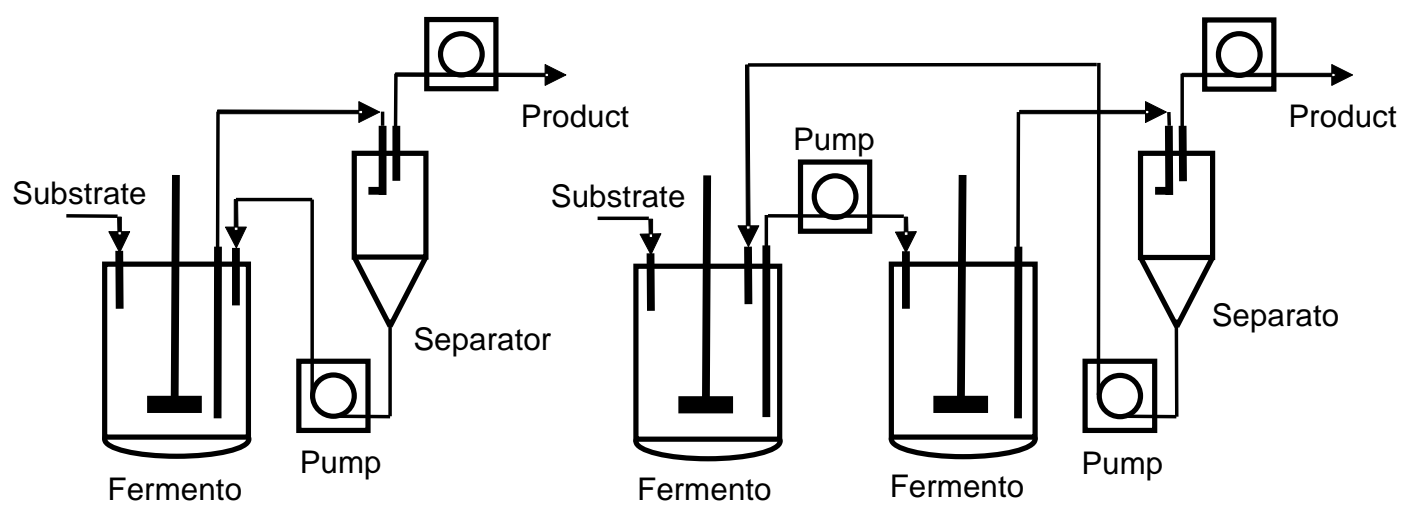

A. Bioreactor

B. Serial Bioreactors

Figure 1. Schematic diagram of fermentation systems with recycling flocculating yeast in (A) a single bioreactor, (B) two bioreactors in series.

\subsection{Continuous cultivation using yeast recycling system}

The continuous cultivation was carried out in the bioreactor with total liquid volume of $1 \mathrm{~L}$ at $30{ }^{\circ} \mathrm{C}$, pH 5.0 and stirring rate of $500 \mathrm{rpm}$. A peristaltic pump (Watson Marlow Alitea AB, Sweden) was used for feeding the substrate into the bioreactor. A glass separator funnel with $250 \mathrm{ml}$ volume was used as a settler for separating flocculating yeast from effluent. The settler had two outlets: a down-flow line equipped with peristaltic pump continuously brought the yeast back to the bioreactor, and an up-flow line placed on the top of separator which is equipped with a controlled pump for drawing the product out of the process (Figure 1A). This pump was controlled by the liquid level in the bioreactor. A vacuum pressure inside the settler allowed a rich yeast solution to flow into the settler, through an inlet line which was designed to give a tangential effect; thus better separation could be carried out.

In addition to the previous system, another 2-liters Biostat-A bioreactor was inserted between bioreactor and separator. The down-flow line of the settler was pumped into first bioreactor, and the outlet of the first bioreactor was fed by a peristaltic pump into the inlet of second bioreactor (Figure 1B). Both bioreactors were operated at conditions (working volume, $\mathrm{pH}$, temperature and stirring rate) similar to those in cultivation with a single bioreactor.

All continuous cultivation were started with batch cultivation on DSM medium with $50 \mathrm{~g} / \mathrm{L}$ glucose as carbon and energy source with total liquid volume of $1 \mathrm{~L}$ at $30^{\circ} \mathrm{C}, \mathrm{pH} 5.0$ and stirring rate of 500 rpm. Air was continuously purged at a rate of $800 \mathrm{~mL} / \mathrm{min}$ to perform aerobic cultivation. A $5 \mathrm{~mL}$ homogenized inoculum was used to start the batch cultivation. Aerobic continuous cultivation was then carried out to provide high cell concentration by feeding completely defined synthetic medium containing $20 \mathrm{~g} / \mathrm{L}$ glucose at dilution rate of $0.1 \mathrm{~h}^{-1}$ until desired cell density was achieved. Completely defined synthetic medium containing $20 \mathrm{~g} / \mathrm{L}$ glucose or sole hydrolyzates were used as substrates in anaerobic cultivation. Rich medium solution was a mixture of hydrolyzate and concentrate DSM solution (5 times of regular DSM concentration) with ratio of 10:1 and was used to increase cell concentration. 


\subsection{Analytical methods}

Samples for HPLC analysis were withdrawn, centrifuged to remove cells and solid materials, and stored at $-20{ }^{\circ} \mathrm{C}$. Glucose, galactose, mannose, furfural and $\mathrm{HMF}$ were analyzed with an ion-exchange Aminex HPX-87P column (Biorad, Hercules, CA) at $85^{\circ} \mathrm{C}$. Ultra-pure water was used as the eluent at a flow of $0.6 \mathrm{~mL} / \mathrm{min}$. Glycerol, acetic acid and ethanol were analyzed by using an Aminex HPX-87H column (Biorad) at $60{ }^{\circ} \mathrm{C}$ with $5 \mathrm{mM} \mathrm{H}_{2} \mathrm{SO}_{4}$ eluent at $0.6 \mathrm{~mL} / \mathrm{min}$. An ultraviolet absorbance (UV) detector (Waters 2486, Waters, Massachusetts, USA) in series with a refractive index (RI) detector (Waters 2410) were used. All component concentrations were determined from the RI detector except furfural and HMF, which were determined from the UV chromatogram at $210 \mathrm{~nm}$ wavelength. Cell dry-mass measurements were carried out in a duplicate by taking aliquots of $10 \mathrm{~mL}$ sample, centrifuged at $4000 \mathrm{rpm}$ for 10 minutes. The cells were washed twice and dried at $110{ }^{\circ} \mathrm{C}$ for $24 \mathrm{~h}$.

The average dimension of flocks was determined by visual observation while the sinking velocity was determined by measuring elapsed time for a sinking flock with diameter around $1 \mathrm{~mm}$ to pass 100 $\mathrm{mm}$ depth. The sinking velocity determination was carried out at least 20 times, and the average velocity was reported.

Every experiment was carried out at least in triplicate, and carbon balances have been evaluated for every batch or continuous run with average standard deviation of $5 \%$. In continuous cultivations, the feed rates were kept constant for at least five retention times in each dilution rate, to be certain of reaching steady-state conditions.

\section{Results}

\subsection{The performance of flocculating yeast}

The flocculating yeast (FY) S. cerevisiae CCUG 53310 was quite fast to flocculate and settled down easily and quickly, which is a clear advantage to be used in cultivation with cell-recycling systems. The flocks had average dimension of $2 \mathrm{~mm}$. They formed aggregates while sinking in cultivation solution. However, the big flocks could be broken by mixing into much smaller cell aggregates (Figure 2). The average sinking velocity was $98 \pm 12 \mathrm{~mm} / \mathrm{sec}$ for flocks with diameter around $1 \mathrm{~mm}$. FY was first characterized and compared with a known lab strain of S. cerevisiae CBS 8066 (CBS). The results are summarized in Figure 3 and Table 1. In addition, FY only took up hexoses i.e. glucose, galactose and mannose. 


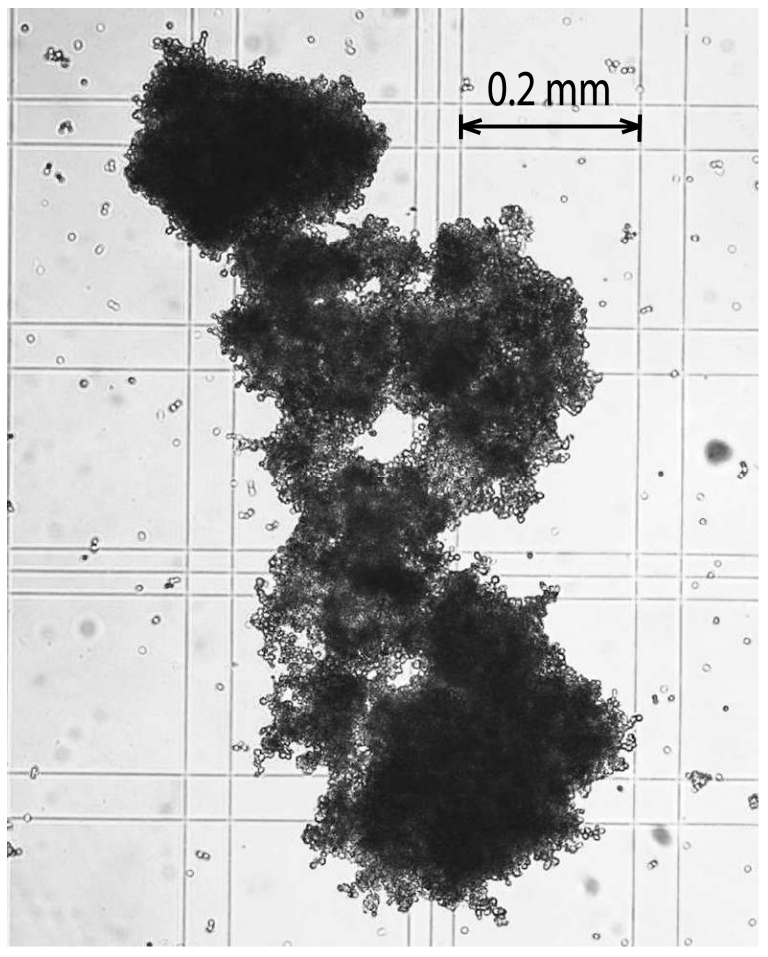

Figure 2. A flock of yeast on a counting chamber under observation by microscope with $50 \mathrm{X}$ magnification.

The flocculating yeast grew aerobically with maximum specific growth rate $\left(\mu_{\max }\right)$ of $0.26 \pm 0.00 \mathrm{~h}^{-1}$, which was somewhat lower than that of the lab strain at identical conditions $\left(0.31 \pm 0.01 \mathrm{~h}^{-1}\right)$. In anaerobic cultivation on glucose, both of the strains had practically similar yields of ethanol, biomass and glycerol (Table 1). On the other hand, FY strain had a longer lag phase in growing on glucose (Figure 3). The lab strain assimilated $95 \%$ of glucose in less than $15 \mathrm{~h}$ while the FY strain took more than 25 hours to reach this level. The FY strain had no deficiency with the components present in the defined medium, since the presence of yeast extract and peptone did not stimulate the specific consumption rate of glucose and ethanol yield (Table 1, Figure 3). However, the YPD medium resulted in a higher biomass yield, compared to the cultivation in the defined medium.

Table 1. Yields (g/g consumed fermentable sugar) of glycerol, ethanol and biomass in anaerobic batch cultivations of the flocculating yeast (FY) and lab strain (CBS) on glucose and hydrolyzate in defined synthetic (DSM) and YPD media. The results were taken after $48 \mathrm{~h}$ of cultivation.

\begin{tabular}{cccc}
\hline Strain and Medium & \multicolumn{3}{c}{ Anaerobic Yield (g/g) } \\
\cline { 2 - 4 } & Glycerol & Ethanol & Biomass \\
\hline CBS + Glu-DSM & $0.04 \pm 0.01$ & $0.47 \pm 0.03$ & $0.10 \pm 0.00$ \\
FY + Glu-DSM & $0.05 \pm 0.01$ & $0.45 \pm 0.02$ & $0.09 \pm 0.01$ \\
FY + Hyd-DSM & $0.04 \pm 0.00$ & $0.46 \pm 0.03$ & $0.11 \pm 0.01$ \\
FY + Glu-YPD & $0.05 \pm 0.01$ & $0.45 \pm 0.03$ & $0.14 \pm 0.01$ \\
\hline
\end{tabular}




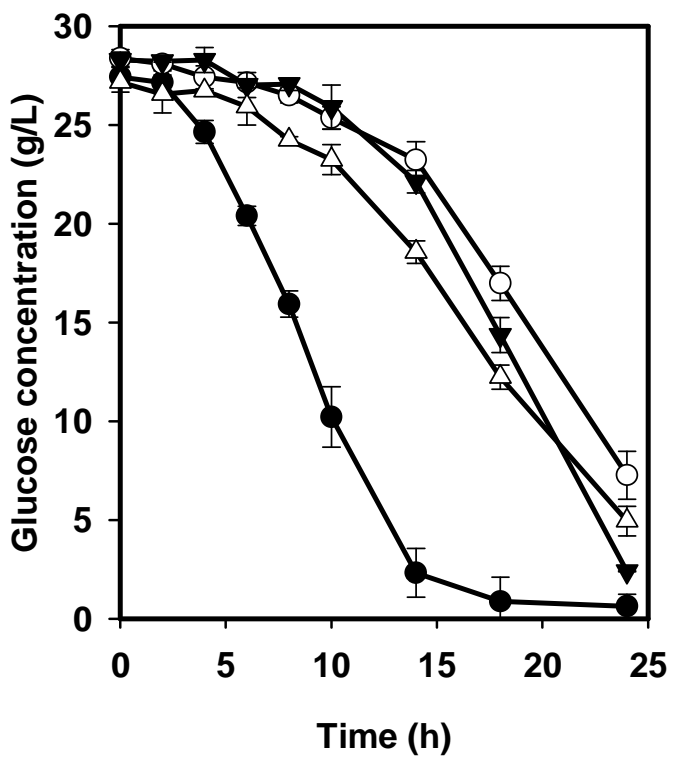

Figure 3. Glucose assimilation on anaerobic batch cultivation of: $(-)$ S. cerevisiae CBS 8066 on glucose and defined synthetic medium (DSM); $(\bigcirc)$ Flocculating yeast on glucose in defined synthetic medium (DSM); $(\boldsymbol{\nabla})$ Flocculating yeast on hydrolyzates in DSM; and $(\triangle)$ Flocculating yeast on glucose in YPD medium.

Flocculating yeast was also evaluated in anaerobic continuous cultivations using $20 \mathrm{~g} / \mathrm{L}$ glucose as carbon and energy source. The cultivations were successfully carried out at dilution rates 0.4 and $0.8 \mathrm{~h}^{-1}$. While the cell concentration in the effluent of the bioreactor was $7.4 \pm 1.7 \mathrm{~g} / \mathrm{L}$ throughout the experiments at different dilution rates, the cell concentration in the effluent of the settler was $0.33 \pm 0.01 \mathrm{~g} / \mathrm{L}$. The cell concentration in the effluent seemed to be independent of dilution rate and cell concentration inside the bioreactor. The ethanol yield in these continuous cultivations was $0.43 \pm 0.01 \mathrm{~g} / \mathrm{g}$ of consumed fermentable sugar.

Table 2. The performance of flocculating yeast in continuous cultivation of dilute-acid hydrolyzate without additional nitrogen source in a single bioreactor equipped with recycling system (Figure 1A) at different dilution rates.

\begin{tabular}{|c|c|c|c|c|c|c|c|c|}
\hline \multirow[t]{2}{*}{$\begin{array}{c}\mathrm{D} \\
\left(\mathrm{h}^{-1}\right)\end{array}$} & \multirow{2}{*}{$\begin{array}{c}\text { Sugar } \\
\text { Assimilation } \\
(\%)\end{array}$} & \multicolumn{2}{|c|}{$\begin{array}{l}\text { Biomass } \\
\text { g-DW/L }\end{array}$} & \multicolumn{3}{|c|}{ Yields* (g/g) } & \multicolumn{2}{|c|}{ Conversion $(\%)$} \\
\hline & & Inside & Out & Ethanol & glycerol & acetate & HMF & Furfural \\
\hline 0.13 & $98.8 \pm 0.4$ & $27.5 \pm 0.02$ & $0.35 \pm 0.01$ & $0.46 \pm 0.02$ & $0.05 \pm 0.03$ & $(0.03 \pm 0.01)$ & $95.9 \pm 3.6$ & $100.0 \pm 0.0$ \\
\hline 0.24 & $98.6 \pm 0.5$ & $23.8 \pm 0.04$ & $0.37 \pm 0.03$ & $0.45 \pm 0.04$ & $0.05 \pm 0.04$ & $(0.03 \pm 0.01)$ & $96.7 \pm 3.2$ & $100.0 \pm 0.0$ \\
\hline 0.38 & $97.7 \pm 0.8$ & $23.3 \pm 0.05$ & $0.34 \pm 0.01$ & $0.44 \pm 0.03$ & $0.07 \pm 0.03$ & $(0.03 \pm 0.00)$ & $94.2 \pm 2.7$ & $100.0 \pm 0.0$ \\
\hline 0.52 & $96.2 \pm 1.8$ & $30.3 \pm 0.01$ & $0.31 \pm 0.02$ & $0.42 \pm 0.02$ & $0.07 \pm 0.02$ & $(0.04 \pm 0.01)$ & $92.1 \pm 3.6$ & $100.0 \pm 0.0$ \\
\hline
\end{tabular}

* Yield in $\mathrm{g} / \mathrm{g}$ assimilated fermentable sugar. 


\subsection{Continuous cultivation of hydrolyzates using flocculating yeast}

The continuous cultivations of the hydrolyzates were carried out successfully with the flocculating yeast at dilution rates $0.13,0.24,0.38$ and $0.52 \mathrm{~h}^{-1}$ (Table 2). It should be noted that the hydrolyzate was so toxic that the $S$. cerevisiae CBS 8066 could not continuously assimilate it at dilution rates higher than $0.1 \mathrm{~h}^{-1}$ (data not shown). However, the flocculating yeast demanded no prior detoxification in order to cultivate the hydrolyzate. Most of the fermentable sugars (glucose, galactose and mannose) present in hydrolyzates could be assimilated by the flocculating yeast, and only $3.8 \%$ of sugar remained in the effluent at the high dilution rate of $0.52 \mathrm{~h}^{-1}$. The cell concentration in these experiments was between 23.3 and $30.3 \mathrm{~g}$-DW/L (Table 2), while the effluent of the settler contained 0.31-0.37 g-DW/L biomass. The highest ethanol yield was obtained in cultivation at the lowest dilution rate $0.13 \mathrm{~h}^{-1}$, and the ethanol yield tends to decrease with dilution rate (Table 2). All furfural and more than $92 \%$ of HMF were converted by the yeast. The acetate present in the hydrolyzate was partly assimilated. Glycerol was the main by-product, with a rather high yield between 0.05 and $0.07 \mathrm{~g} / \mathrm{g}$ (Table 2). During the continuous cultivation, the flocculating yeast was settled quickly in the settler and recycled into the bioreactor. Therefore, the cells had a tendency to accumulate inside the bioreactor, unless it was inhibited by different means or drained. In these experiments the cell growth rate was controlled by limiting the nitrogen source in the media. Providing the rich medium resulted in increased cell concentration to more than $50 \mathrm{~g} / \mathrm{L}$, which was a sticky solution (Figure 4). While no nitrogen source was fed to the bioreactor, the flocculating yeast could survive and produce ethanol from the hydrolyzates for 37 retention times, and its cell concentration remained at $23.3 \pm 1.6 \mathrm{~g}-\mathrm{DW} / \mathrm{L}$. However, addition of the nitrogen source resulted in continuously increased cell concentration inside the bioreactor, while the cell concentration in the effluent of the settler was constant at $0.35 \pm 0.04 \mathrm{~g} / \mathrm{L}$ (Figure 4).

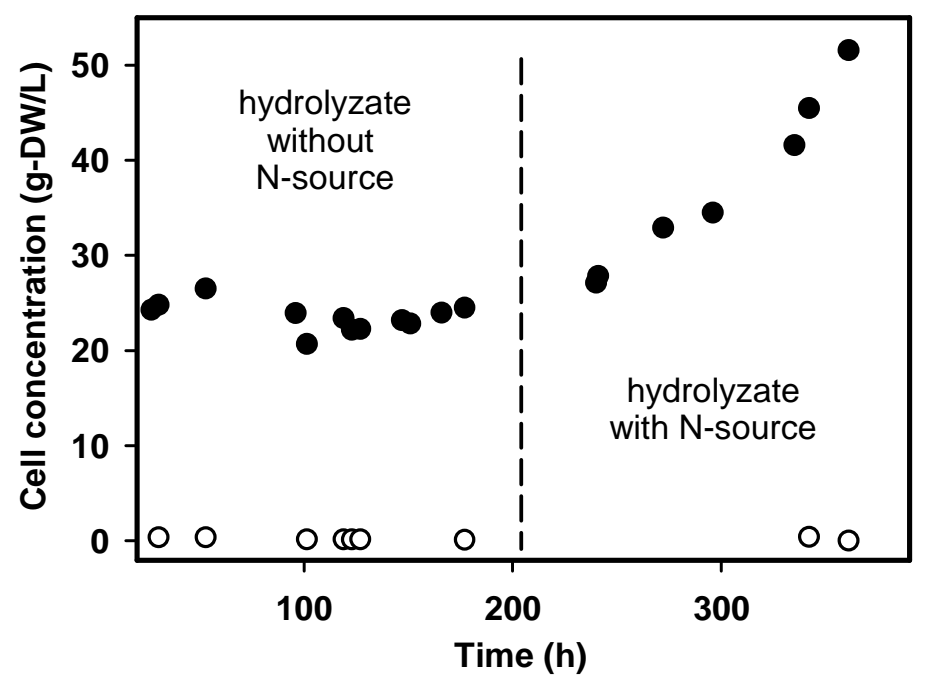

Figure 4. The trend of cell concentration inside the bioreactor $(0)$ and in the effluent of the settler $(\mathrm{O})$ in anaerobic continuous cultivation of the hydrolyzate with the flocculating yeast. The dashed line distinguishes when the nitrogen source was present or absent in the defined medium. 
The effect of cell density on the performance of the flocculating yeast was studied by performing a continuous cultivation of the hydrolyzate at $0.13 \mathrm{~h}^{-1}$ with identical conditions as in the above mentioned experiments (Table 2), but with lower cell mass concentration of $5.6 \mathrm{~g} / \mathrm{L}$. The yeast was previously cultivated aerobically using glucose as a carbon source for $22 \mathrm{~h}$, which was enough time to convert most of the carbon sources into biomass and reach the desired level of the biomass concentration. While the hydrolyzate was introduced into the bioreactor with dilution rate $0.13 \mathrm{~h}^{-1}$, the cells actively consumed the sugars and produced carbon dioxide. However, the $\mathrm{CO}_{2}$ evolution rate reached a maximum level after $2 \mathrm{~h}$ and then gradually decreased to a very low level. In this period, the yeast lost its flocculating characteristic and spread in the bioreactor (data not shown).

Continuous cultivation was also carried out in two bioreactors working in series, where the biomass was recycled from the last bioreactor to the first one (Figure 1B). A high dilution rate was applied in this system and the dynamic behavior of cultivation was monitored. The objective of this experiment was to find out the tolerance of the flocculating yeast to high inflow of the toxic materials (i.e. HMF and furfural) caused by high dilution rate, particularly in the first bioreactor. The experiments were carried out at dilution rates $0.24,0.38$ and $0.52 \mathrm{~h}^{-1}$ based on the total volume of the two bioreactors, which correspond to residence times of $2.08,1.31$ and $0.96 \mathrm{~h}$ in the first bioreactor, respectively. The cultivations were continued for $145 \mathrm{~h}$, and the results are summarized in Table 3 . The cultivations at all the dilution rates were successful and the cells were able to tolerate the high inflow of the inhibitors and assimilate the sugars. The biomass concentrations in both of the bioreactors were similar and in the range of 25.0-35.1 g/L at different dilution rates (Table 3). However, the biomass concentration in the effluent of the settler was quite low at $0.28 \pm 0.02 \mathrm{~g} / \mathrm{L}$. The sugar residuals in the effluent were in the range of the sugar residuals for the corresponding dilution rate in a single bioreactor (cf. Table 2 vs. 3 ). However, the sugar residual in the effluent of the first bioreactor was higher (Table 3). No significant differences in ethanol yield were observed, whether a single or a serial bioreactor was used (cf. Table 2 and 3).

Table 3. The performance of flocculating yeast in continuous cultivation of dilute-acid hydrolyzate in a serial bioreactor equipped with recycling system (Figure 1B) at different dilution rates. The dilution rates are based on the total volume of both bioreactors.

\begin{tabular}{|c|c|c|c|c|c|c|}
\hline \multirow[t]{2}{*}{$\begin{array}{c}\mathrm{D} \\
\left(\mathrm{h}^{-1}\right)\end{array}$} & \multicolumn{2}{|c|}{ Sugar Assimilation (\%) } & \multicolumn{2}{|c|}{$\begin{array}{l}\text { Biomass } \\
\text { g-DW/L }\end{array}$} & \multicolumn{2}{|c|}{$\begin{array}{c}\text { Total Yield } \\
(\mathrm{g} / \mathrm{g})\end{array}$} \\
\hline & $1^{\text {st }}$-fermentor & $2^{\text {nd }}-$ fermentor & Inside & Out & Ethanol & Glycerol \\
\hline 0.24 & $98.2 \pm 0.3$ & $98.3 \pm 0.3$ & $25.0 \pm 0.06$ & $0.29 \pm 0.03$ & $0.42 \pm 0.01$ & $0.05 \pm 0.00$ \\
\hline 0.38 & $92.6 \pm 1.3$ & $96.3 \pm 0.4$ & $27.6 \pm 0.03$ & $0.30 \pm 0.01$ & $0.43 \pm 0.00$ & $0.08 \pm 0.00$ \\
\hline 0.52 & $87.6 \pm 0.9$ & $94.3 \pm 0.5$ & $35.1 \pm 0.04$ & $0.27 \pm 0.03$ & $0.43 \pm 0.01$ & $0.08 \pm 0.00$ \\
\hline
\end{tabular}




\section{Discussion}

Flocculating yeast was successfully cultivated to produce ethanol from undetoxified dilute-acid hydrolyzate in continuous mode of operation at high dilution rates. This could be a breakthrough in cultivation of toxic lignocellulosic hydrolyzates. In a traditional chemostat process, the presence of inhibitors such as furfural can be tolerated only at low concentrations of the inhibitors and low dilution rates [24]. However, if the cells remain in the bioreactor through e.g. immobilization [33] or encapsulation [29], it would be possible to achieve a higher dilution rate in a continuous cultivation. Talebnia and Taherzadeh [29] showed that the cells present in a colony in e.g. a capsule can protect each other against the inhibitors in cultivation of toxic hydrolyzate. There is probably a similar phenomenon in continuous cultivation of the toxic hydrolyzates with flocculating yeast, since yeast cells are also present in colonies (cf. Fiure.2). There is no clear explanation yet regarding how the colonies can survive due to inhibition. However, the morphology of the cells which stick together with high numbers of cell members probably gives a possibility for the cells to work in concert and protect each other against inhibitors. This means that the cells at the outer layer of the population are sacrificed and protect the other cells by converting toxic materials.

Cultivation of the lignocellulosic hydrolyzate was tested in single and serial bioreactors up to dilution rates $0.52 \mathrm{~h}^{-1}$, based on the total volume in the bioreactors. No specific improvement on decreasing the residual sugars was observed in using serial bioreactors. In other words, dividing of the total volume into two bioreactors did not help in decreasing the residual sugar concentrations. An extra bioreactor is probably necessary in order to assimilate the residual sugars in serial bioreactors, when a high dilution rate is applied. However, it should be noticed that the first bioreactor could successfully convert more than $87 \%$ of the incoming sugars in a residence time of less than one hour. The inhibitors could not inhibit the cells at this very high dilution rate.

An important advantage of this flocculating yeast is being extremely fast to flocculate and quickly settle down. The yeast flocks can break down under mechanical shear forces such as those from a mixing impeller or pump. But when reaching a stagnant region, they tend to stick back onto each other and start to re-flocculate. Obviously, this property gives an opportunity to use simple separation equipment which reduces investment and operating costs. Furthermore, the cell content in the settler effluent is independent of both flow rate and cell concentration in a bioreactor. Therefore, the cells can grow in a favorable environment and accumulate until a concentration of more than $50 \mathrm{~g}-\mathrm{DW} / \mathrm{L}$, which is an extremely high cell concentration as compared with ordinary cultivation. This advantageous flocculating property is a key factor for keeping high cell concentration in a bioreactor so that the system has a capability of fermenting a toxic material.

Mass transfer problems are a drawback of flocculating yeast. There are two important mass transfers regarding microorganism cells: glucose transport and oxygen transport. The latter does not occur in anaerobic cultivation subjected to ethanol production. Diffusivity coefficients of glucose in the aggregates of flocculating yeast are about $17 \%$ compared with those in pure water [38]. Consequently, flocculating cells takes approximately twice the time of free cells to complete anaerobic cultivation (Figure 3). Mixing rates could help to resolve the mass transfer problems, but high mechanical stress would be harmful to the microorganism. As a result, flocculating yeast has a lower specific growth rate than free cells, which can be compensated by using a high cell concentration in the bioreactor. 
It can be concluded that the continuous cultivation of lignocellulosic hydrolyzates can be successfully carried out by using flocculating yeast at high cell concentration and high dilution rate. No prior detoxification is necessary and the continuous cultivation is possible to convert hydrolyzates into ethanol in two hours (at dilution rate of $0.5 \mathrm{~h}^{-1}$ ). This may be a key advance in cultivation of the toxic lignocellulosic hydrolyzate after three decades of research.

\section{Acknowledgments}

This work was financially supported by the Swedish Energy Agency and the University College of Borås. Dr. Robert Eklund and his colleagues are thanked for providing the hydrolyzates used in this work. The flocculating yeast was kindly provided by Domsjö Fabriker AB.

\section{References}

1. Rosillo-Calle, F.; Walter, A. Global market for bioethanol: historical trends and future prospects. Energy Sustain. Devel. 2006, 10, 20-32

2. Chen, G.; Li, S.; Jiao, F; Yuan, Q. Catalytic dehydration of bioethanol to ethylene over $\mathrm{TiO}_{2} / \mathrm{Al}_{2} \mathrm{O}_{3}$ catalysts in microchannel reactors. Catal. Today 2007, 125, 111-119

3. Golay, S.; Doepper, R.; Renken, A. Reactor performance enhancement under periodic operation for the ethanol dehydration over $\gamma$-alumina, a reaction with a stop-effect. Chem. Eng. Sci. 1999, $54,4469-4474$

4. Moreira, J.R.; Goldemberg, J. The alcohol program Energy Policy 1999, 27, 229-245

5. Gil, G.H.; Jones, W.J.; Tornabene, T.G. Continuous ethanol production in a two-stage, immobilized/suspended-cell bioreactor Enzyme Microb. Technol. 1991, 13, 390-399

6. Deepchand, K.; Baguant, J. Utilization of cane tops and leaves for energy and food -- an integrated system Biomass 1985, 7, 215-223

7. Turhollow, A.F.; Heady, E.O. Large-scale ethanol production from corn and grain sorghum and improving conversion technology Energy Agric. 1986, 5, 309-316

8. Mullins, J.T.; NeSmith, C. Integrated ethanol production and utilization system for small farms Biomass 1984, 6, 155-166

9. Bengtson, H.H. Small scale ethanol production from corn -- technology, energy efficiency and economics Energy Agric. 1983, 2, 197-217

10. Ladisch, M.R.; Tsao, G. T. Engineering and economics of cellulose saccharification systems Enzyme Microb. Technol. 1986, 8, 66-69

11. Meo, M. Economic evaluation of ethanol fuel production from agricultural crops and residues in California Resour. Conserv. 1984, 11, 1-25

12. Galbe, M.; Zacchi, G. A review of the production of ethanol from softwood Appl. Microbiol. Biotechnol. 2002, 59, 618-628

13. Saeman, J.F. Kinetics of wood saccharification: Hydrolysis of cellulose and decomposition of sugars in dilute acid at high temperature Ind. Eng. Chem. 1945, 37, 43-52

14. Jorgensen, H.; Kutter, J.P.; Olsson, L. Separation and quantification of cellulases and hemicellulases by capillary electrophoresis Anal. Biochem. 2003, 317, 85-93 
15. Zhang, Y.-H.P.; Himmel, M.E.; Mielenz, J.R. Outlook for cellulase improvement: Screening and selection strategies Biotechnol. Adv. 2006, 24, 452-481

16. Palmqvist, E.; Hahn-Hägerdal, B. Fermentation of lignocellulosic hydrolysates. II: inhibitors and mechanisms of inhibition Bioresour. Technol. 2000, 74, 25-33

17. Taherzadeh, M.J.; Gustafsson, L.; Niklasson C.; Liden G. Inhibition effects of furfural on aerobic batch cultivation of Saccharomyces cerevisiae growing on ethanol and/or acetic acid $J$. Biosci. Bioeng. 2000, 90, 374-380

18. Taherzadeh, M.J.; Gustafsson, L.; Niklasson, C.; Lidén, G. Physiological effects of 5hydroxymethylfurfural on Saccharomyces cerevisiae Appl. Microbiol. Biotechnol. 2000, 53, 701-708

19. Olsson, L.; Hahn-Hägerdal, B. Fermentative performance of bacteria and yeasts in lignocellulose hydrolysates Process Biochem. 1993, 28, 249-257

20. Leonard, R.; Hajny, G. Fermentation of wood sugars to ethyl alcohol Ind. Eng. Chem. 1945, 37, 390-395

21. Martinez, A.; Rodriguez, M.E.; York, S.W.; Preston, J.F.; Ingram, L.O. Effects of $\mathrm{Ca}(\mathrm{OH})_{2}$ treatments ("overliming") on the composition and toxicity of bagasse hemicellulose hydrolysates Biotechnol. Bioeng. 2000, 69, 526-536

22. Parajo, J.C.; Dominguez, H.; Dominguez, J.M. Charcoal adsorption of wood hydrolysates for improving their fermentability: Influence of the operational conditions Bioresour. Technol. 1996, 57, 179-185

23. Taherzadeh, M.J.; Niklasson, C.; Lidén, G. Conversion of dilute-acid hydrolyzates of spruce and birch to ethanol by fed-batch fermentation Bioresour. Technol. 1999, 69, 59-66

24. Horvath, I.S.; Taherzadeh, M.J.; Niklasson, C.; Lidén, G. Effects of furfural on anaerobic continuous cultivation of Saccharomyces cerevisiae Biotechnol. Bioeng. 2001, 75, 540-549

25. Kishimoto, M.; Nitta, Y.; Kamoshita, Y.; Suzuki, T.; Suga, K.-I. Ethanol production in an immobilized cell reactor coupled with the recycling of effluent from the bottom of a distillation column J. Ferment. Bioeng. 1997, 84, 449-454

26. Najafpour, G.; Younesi, H.; Syahidah Ku Ismail, K. Ethanol fermentation in an immobilized cell reactor using Saccharomyces cerevisiae Bioresour. Technol. 2004, 92, 251-260

27. Ogbonna, J.C.; Mashima, H.; Tanaka, H. Scale up of fuel ethanol production from sugar beet juice using loofa sponge immobilized bioreactor Bioresour. Technol. 2001, 76, 1-8

28. Koyama, K.; Seki, M. Cultivation of yeast and plant cells entrapped in the low-viscous liquidcore of an alginate membrane capsule prepared using polyethylene glycol J. Biosci. Bioeng. 2004, 97, 111-118

29. Talebnia, F.; Taherzadeh, M.J. In situ detoxification and continuous cultivation of dilute-acid hydrolyzate to ethanol by encapsulated S. cerevisiae J. Biotechnol. 2006, 125, 377-384

30. Brandberg, T.; Sanandaji, N.; Gustafsson, L.; Franzen, C.J. Continuous Fermentation of Undetoxified Dilute Acid Lignocellulose Hydrolysate by Saccharomyces cerevisiae ATCC 96581 Using Cell Recirculation Biotechnol. Prog. 2005, 21, 1093-1101

31. Bailey, J.E. and Ollis, D.F. Biochemical Engineering Fundamental; McGraw-Hill: New York, 1986 
32. Verstrepen, K.J.; Derdelinckx, G.; Verachtert, H.; Delvaux, F.R. Yeast flocculation: what brewers should know Appl. Microbiol. Biotechnol. 2003, 61, 197-205

33. Taherzadeh, M.J.; Millati, R.; Niklasson, C. Continuous cultivation of dilute-acid hydrolysates to ethanol by immobilized Saccharomyces cerevisiae Appl. Biochem. Biotechnol. 2001, 95, 4557

34. Millati, R.; Niklasson, C.; Taherzadeh, M.J. Effect of $\mathrm{pH}$, time and temperature of overliming on detoxification of dilute-acid hydrolyzates for fermentation by Saccharomyces cerevisiae Process Biochem. 2002, 38, 515-522

35. Franzen, C.J.; Albers, E.; Niklasson, C. Use of the inlet gas composition to control the respiratory quotient in microaerobic bioprocesses Chem. Eng. Sci. 1996, 51, 3391-3402

36. Purwadi, R.; Niklasson, C.; Taherzadeh, M.J. Kinetic study of detoxification of dilute-acid hydrolyzates by $\mathrm{Ca}(\mathrm{OH})_{2}$ J. Biotechnol. 2004, 114, 187-198

37. Taherzadeh, M.J.; Niklasson, C.; Lidén, G. Acetic acid--friend or foe in anaerobic batch conversion of glucose to ethanol by Saccharomyces cerevisiae? Chem. Eng. Sci. 1997, 52, 2653-2659

38. Vicente, A.A.; Dluhy, M.; Ferreira, E.C.; Mota, M.; Teixeira, J.A. Mass transfer properties of glucose and $\mathrm{O}_{2}$ in Saccharomyces cerevisiae flocs Biochem. Eng. J. 1998, 2, 35-43

(C) 2007 by MDPI (http://www.mdpi.org). Reproduction is permitted for noncommercial purposes. 